\title{
Patent nonsense: Evidence tells of an industry out of social control
}

\author{
Henry Mintzberg
}

An abridged version of this article appeared in the Aug. I5, 2006, issue of CMAJ.

W hat enables the patent-dependent pharmaceutical companies to set the prices they do? Two factors. The first is economic: the companies that make (or at least secure the right to) the discoveries in this marketplace of ideas reap the rewards. The second is legal: governments grant those companies monopolies, in the form of patent protection, for what is called their "intellectual property." ${ }^{1}$

Usually, governments that have granted such important monopoly powers in the marketplace, for example in electricity and telephone services, have regulated prices carefully and those that did not have often suffered the consequences. Most countries do, in fact, attempt to control pharmaceutical prices. But the United States, which generally does not, has recently used its bilateral and regional free trade negotiations with countries such as Australia, Peru, Guatemala and other Central American countries to weaken their ability to control drug prices. ${ }^{2-7}$

In late 2003, an article in The New York Times stated: "Having beaten back price controls on prescription drugs in the United States, the American pharmaceutical industry is trying to roll them back overseas, with help from the [Bush] administration and Congress. In talks over a free trade agreement with Australia, American officials are pressing to water down the system under which the Australian government negotiates the prices it pays for prescription drugs, [said] Mark Vaile, the Australian minister for trade." In May 2004 the Australian government acquiesced to those demands. ${ }^{3}$ Pressures brought on other countries in bilateral trade negotiations were labelled as tantamount to "blackmail" by the President of the French Republic. ${ }^{8}$

As long as the pharmaceutical companies exercised some kind of restraint on pricing, the system seemed to work, more or less. But with the advent of "shareholder value," which drives executives to push up company share prices, publicly traded companies have been driven to charge what the market will bear. However, what the market will bear is not necessarily what the ill can afford. ${ }^{9}$

In I998, a coalition of most of the world's large patentdependent pharmaceutical companies, including some previously known for their social responsibility, initiated legal ac$n$ tion against the government of South Africa, to block efforts to reduce prices of HIV/AIDS medications. Subsequent reports in the press put the Western price of an annual treatment with a cocktail of patented drugs in the range of \$10 000-\$15000, whereas at least one generic producer claimed that it could supply the necessary drugs to the South African government for $\$ 350 .{ }^{10}$ The pharmaceutical industry, reacting to the result- ing publicity, withdrew its suit in $200 \mathrm{I}$ and agreed to pay the South African government's legal costs. ${ }^{11}$

What prompted these companies to mount such a challenge in the first place? It could be argued that, in order to maintain a system so beneficial to themselves, they had no choice. If price reductions could be made for poor South Africans, then why not for poor Americans? Indeed, why not for middle-income Americans, especially when "[e]mployers and insurers keep shifting chunks of the tab for drugs to patients," with the result, according to one industry analyst, that in certain cases "as prices go up, people consume less"? backing down in South Africa, the pharmaceutical companies revealed how questionable that system is in America.

The pharmaceutical industry, which calls itself research based but which I herein refer to as "patent-dependent," can be represented by a framework of 4 stages in its chain of operations (Fig. I).

Research leads to patentable products, the prices of which are justified by its costliness and riskiness. ${ }^{13}$ Development carries the patent to registration through rather intricate testing, which can also be costly, although this stage tends to be more structured and therefore more easily managed. Manufacturing is relatively straightforward and often relatively modest in cost, averaging about $3 \%$ of the ex-factory price by one estimate. ${ }^{14}$ Finally promotion, including the marketing and selling of products, tends also to be very costly.

In this article, I draw on evidence from articles in medical journals and the business and general press to describe the "patent nonsense" of granting public monopolies to private companies, on products that can determine the life or death of the user, with insufficient control of prices. This is largely the situation in the United States today and will extend to other parts of the world if the concerted efforts by the US government succeed. ${ }^{15}$ I discuss the issues surrounding the high price of pharmaceuticals using the framework in Fig. I, integrating a variety of arguments to provide a conceptual overview of an industry concluded to be out of social control. Appendix I provides specific examples of behaviours that illustrate this.

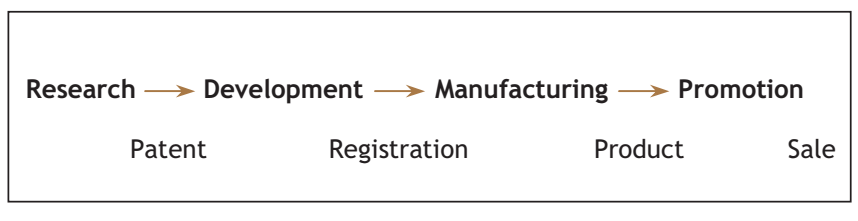

Fig. 1: Framework representing chain of operations of pharmaceutical companies. 


\section{Research}

The pharmaceutical companies' prime justification for their pricing, namely performance in costly and risky research, may in fact prove to be the weakest link in their chain of argument as well as their chain of operations.

Certainly financial incentives are required to support commercial investments in research. But to what extent? In a $200 \mathrm{I}$ article in Business Week magazine, Carey and coauthors commented that, "although drugmakers spend billions on R\&D, they also rake in huge profits. Too big, some analysts believe. Since I 198 , the return on equity of the five biggest US based drugmakers ... has averaged 30\% a year," far in excess of the Standard \& Poor's 500-stock index..$^{16}$ The claimed riskiness of this "ought to translate into variable returns." Yet "drugmakers show a consistently higher return on equity compared with companies in other sectors." Their conclusion: this industry's "prices are higher than needed to cover R\&D costs and risks." However, "the price set for a drug has little to do with its development cost. ... The producers charge what the market will bear."

How well do the pharmaceutical companies perform this research? There have certainly been impressive accomplishments, but disturbing evidence is now accumulating of an industry increasingly troubled by its research record.

The Business Week article cited above wrote about these companies "filling their pipelines by picking up drugs from biotech corporations and startups - after the medicines have already shown promise in clinical trials." ${ }^{\text {16 }}$ A 2002 article in The Economist wrote of an industry "losing its knack for producing wonder drugs, ${ }^{17}$ and a 2003 editorial in the British Medical Journal referred to "concerns ... about the productivity of research being funded by the major pharmaceutical companies." ${ }^{18}$ In 2004, The Wall Street Journal reported that "Last year, the Food and Drug Administration only approved 2I new drugs, marking a steady decline since a peak of 53 in 1996. Many of the world's largest drug companies failed to win US approval for a single new drug in 2003. The dearth of new products has forced companies to seek growth by heavily promoting their pills and extending product lines through minor modifications." ${ }^{19}$ Concerning the latter, known as "me-too" drugs, Light and Lexchin cited evidence that "only I0-I5\% of 'new' drugs provide a significant therapeutic breakthrough over existing drugs" and only "about $18 \%$ of the drug industry's research budget goes to basic research for breakthrough drugs." ${ }^{20,21}$

These problems may be explained by recent structural changes in the pharmaceutical industry, including consolidation through mergers, expansion of leading companies to unprecedented size, and the advent of "shareholder value," which drives executives to push up company share prices, thereby breeding a short-term, results-driven mentality antithetical to thoughtful research.

Large scale may be an impediment to effective research. So said Raymond Gilmartin, chief executive of Merck, long renowned for its research: "Scale has been no indicator of the ability to discover breakthrough drugs. In fact, it has been the other way - you get bogged down." 22 Yet scale is on the rise, as is industry concentration, in consequence especially of company mergers. ${ }^{23}$

A 2003 article in The New York Times reported that " 9 top scientists" had recently left GlaxoSmithKline because they believed "its laboratory productivity was getting worse, not better. 'It's a disaster,' said one of them, Dr. Peter G. Traber, who was the company's chief of clinical development until February." He added: "The effect of mergers on research productivity is an issue that this industry has yet to deal with." ${ }^{24}$ Thus, a 2004 article in the Financial Times about Pfizer, the company that has been most heavily engaged in mergers, claimed "that while it was out deal-making, its own research dried-up." 25

But the problem appears to extend beyond mergers. Merck, the company often regarded as "a paragon of American science" and that "shunned mergers" as distractions "from its mission of finding innovative medicines," has been finding itself bogged down. By late 2003, according to The Wall Street Journal, with the exception of one new product, "the cupboard [was] virtually bare."23

Research in organization theory has long indicated the effects of company size on the bureaucratization of its procedures. ${ }^{26}$ Systems become more formal, relationships more impersonal, categories more reified. This can have an especially stifling influence on research, which tends to thrive in open, flexible structures. These are hardly implied by the chief executive of Pfizer as he took office in 200I, when he pointed "to the newly doubled library of two million compounds that the company can now screen for possible new drug combinations. 'We now have essentially twice the chances of finding a quality candidate in the discovery process'." ${ }^{22}$ Claimed the chief executive of another pharmaceutical company: "We had expected a lot more [new drugs] by this time. ... The reason [for their absence] is that the new stuff is difficult to find. ${ }^{16}$ But are pharmaceutical discoveries found, or do they have to be created?

A Wall Street Journal article of 2004 under the heading "Drug Maker, heal thyself," offered an apt conclusion to this discussion: "When the going gets tough, the tough raise prices. With few new products to launch, major drug makers have been raising the sticker prices of medicines already on the U.S. market, where they're freest to do so."12

\section{The skewing of research priorities}

We all benefit from the research, or so the industry claims. However, only those who can afford its results benefit from the research. And globally that excludes a great many people who are ill or die for want of available medicinal treatments. Although this most obviously occurs in developing countries, increasingly it also includes Americans, not only those who are poor but also middle-income people who lack adequate insurance protection. ${ }^{12,27}$

Moreover, only people whose needs are addressed by the research benefit from it. And that, too, excludes many people. It has been claimed that the greatest advance in health care was the cleaning up of the water supply. What incentive does any pharmaceutical company have to do the equivalent of that 
today? Indeed, how much incentive is there to study the causes of an illness (e.g., breast cancer) instead of researching possible cures? The eradication of a disease, or at least its prevention, eliminates the demand for drugs to treat it. A New York Times editorial in 2001 noted that "The pharmaceutical industry has been reluctant to undertake the necessary research" on vaccines because a one-shot inoculation is less lucrative financially than continuous treatment of a chronic illness. Moreover, the "market for vaccines is mainly in poor nations. ${ }^{28}$ In their analysis reported in The Lancet in 2002 of the outcomes of pharmaceutical research and development over the past 25 years, Trouiller and associates ${ }^{29}$ found that diseases occurring predominantly in "the developing world [were] largely unaddressed. ...[O]f 1393 new chemical entities marketed between 1975 and 1999 , only I6 were for tropical diseases and tuberculosis."

Thus, a consequence of having so much research done by the pharmaceutical companies, by virtue of the huge profits available to them, is that research priorities can be skewed. This has been discussed in another 2002 article in The Lancet, by Collier and Iheanacho, ${ }^{30}$ who noted that "as increasing numbers of medical researchers are drawn to the industry, alternative voices and opinions can become muted, and novel avenues of research might be overlooked."

It may be time to take a careful look at who does pharmaceutical research, in what ways, for what purposes and with what consequences. ${ }^{31,32}$ Certainly there is an important role to be played by the large patent-dependent pharmaceutical companies, although if current trends continue, it may be more in development than in research. And smaller companies clearly have much to contribute in certain critical spheres of research. But we may have lost sight of the important role of other institutions as well as other incentives for discovery.

Consider 3 of the most significant pharmaceutical-related discoveries of the 2oth century: penicillin, insulin and the polio vaccine. All came from the laboratories of not-for-profit institutions. Their incentives were clearly not primarily financial. (Indeed, that continues to be true for most of the research in medical practices today.) Working in such institutions may in fact contribute to the effectiveness of the researchers. Imagine Alexander Fleming in a corporate laboratory today, expected to maximize the "value" for shareholders he's never met while having to look at all those compounds on a computer screen. What incentive would he have to see the potential of those bacteria in that mould? It has been said of Benjamin Franklin, who "made no effort to patent or profit from any of his inventions," that it was his "indifference to the things of this world" that unleashed his full creative powers. ${ }^{33}$

\section{Intellectual property}

"Intellectual property" appears to be a simple enough concept: to the maker of the discovery goes the benefits. But a pharmaceutical discovery is not a piece of land around which lines can be drawn. Discoveries flow into one another, and depend on each other. In particular, "downstream" discoveries, namely marketable products, often depend on "up- stream" discoveries in basic research. Yet the former can be more easily patented than the latter because they are more tangible, and so companies that operate downstream may be able to benefit financially from discoveries made by not-forprofit institutions upstream.

Much of the upstream research is government subsidized, which means that tax dollars may be converted into profits for pharmaceutical companies. A US Congress report of 2000 noted that "Of the 2I most important drugs introduced between 1965 and 1992, 15 were developed using knowledge and techniques from federally funded research." ${ }^{34}$ In one case, a company "benefited from substantial investments in research conducted or funded by the NIH [National Institutes of Health]," with sales of the products amounting to $\$ 9$ billion between 1993 and 2002. The company gave the NIH \$35 million in royalty payments, a small fraction of what the NIH estimated to be its own spending on the related research. ${ }^{35}$

Besides the possible financial distortions, the very need to isolate a product for patent application - to prove that a company has the right to its ownership - may interfere with the discovery process itself, which is facilitated by a certain openness of information and a free sharing of ideas. ${ }^{30}$ Thus, when the chief executive of Eli Lilly claimed, in a Wall Street Journal commentary entitled "Hands off my industry," that the risky and costly business of funding new medicines requires two important principles to guarantee the financial returns needed to encourage investment in R\&D, namely "a market-based system of pricing, and intellectual property protection," ${ }^{13}$ a greater truth might lie in exactly the opposite conclusion: that both may now be interfering with advances in the treatment of critical illnesses. Through various recent trade agreements, it certainly appears that this will be interfering further with the actual treatment of many illnesses, especially in developing countries, by encouraging and perpetrating excessively high prices. ${ }^{36,37}$

\section{Development}

The pharmaceutical companies are increasingly letting biotechnology companies and start-up companies "take the big risks of research." They then buy their innovations and develop them. "The evidence clearly suggests that smaller, younger organizations are more likely to deliver true innovations," claimed a pharmaceutical executive. ${ }^{16}$

That approach may be reasonable. But the profits resulting from it may not be. It is telling that Pfizer, the company known especially for mergers and for buying or licensing its way into new products, ${ }^{38}$ has become by far the largest pharmaceutical company and the most profitable.

Some of the profits, of course, end up with the small firms that make the discoveries. But much ends up with the buyers of these innovations, and that has to do with market power, not research. The small firms may be adept at doing some of the downstream research but are less so at doing much of the development. Here is where scale can be helpful, and indeed the formal procedures of the large companies. In fact, given their size and position in certain market segments, as a consequence of their established channels of distribution and 
massive expenditures on promotion, these companies can become the de facto gatekeepers of the registration and distribution processes. As such, they can reap huge economic benefits. Of course, no company can justify these profits on the basis of development and promotion alone. So the large pharmaceutical companies justify their profits on the basis of research - even when it is not their own.

\section{Promotion}

At the end of the pharmaceutical chain of operations is promotion, much of which may benefit the companies at the expense of their customers.

The expenditures to pull the products through the channels, via physicians to users, are enormous. Fortune magazine has described Pfizer as a "marketing machine" that "spends roughly $39 \%$ of its revenues ... on sales and marketing," more, in fact, than it spends on research and development. To this must be added the time required of physicians. (The industry alone reportedly spends $\$ 6000$ to $\$$ II 000 per physician per year. ${ }^{39}$ ) A study involving medical school graduates of McMaster University and the University of Toronto found that the former group, having been prohibited from meeting pharmaceutical company representatives at school, had less contact with these representatives and were less likely to find such contacts helpful than were the Toronto graduates. ${ }^{40}$

Clearly promotion adds greatly to the costs of pharmaceuticals. But what does it add to the benefits for the buyers?

"Promotion" is not meant to inform in any balanced way, but rather to convey the advantages of a product while obscuring its disadvantages. A reliance on promotion to inform about pharmaceutical products can thus lead to distortions in their use and to excessive prescribing, especially given the growing, and questionable, practice of advertising directly to consumers. ${ }^{41}$ (Pharmaceuticals come under prescription precisely because informed professionals must decide on their use. Subjecting those professionals to the pressures of patients informed by one-sided advertising hardly helps to improve these decisions.)

Companies are "spending billions on ads that critics say are often misleading," according to a Business Week article in 200I; indeed, "as many as two-thirds of people taking Schering-Plough Corp's heavily advertised Claritin [while it was still on patent] and other allergy medicines don't even have allergies." ${ }^{16}$ An article in The Lancet highlighted how "heavily dependent" society has become on industry sources for its pharmaceutical information. ${ }^{14}$ "Timely, independent, comprehensive, and accurate information on new drugs is hard to find," ${ }^{27}$ noted 2 health policy academics. Might not health care be better served by having independent clearinghouses screen and make available all the relevant information on pharmaceutical treatments?

A great deal has been revealed in recent years about biases in pharmaceutical companies' reports on their medicines. These include "the preponderance of positive companysponsored studies," threats of "legal action to stop nominally independent researchers from publishing negative material" and research contracts that allow "the sponsoring company to delete information from the report and to delay publication." ${ }^{30}$ Embarrassed by this, some pharmaceutical companies have announced changes in their intentions to report.

Particularly insidious is that "advertising firms are now running clinical trials," as Light and Lexchin put it. ${ }^{20}$ To quote from a 2002 article in The New York Times: "Madison Avenue ... is expanding its role in the drug business, wading into the science of drug development. The three largest advertising companies ... have spent tens of millions of dollars to buy or invest in companies ... that perform clinical trials of experimental drugs. ... 'You cannot separate the advocacy and marketing from the science anymore,' said ... a former editor of The New England Journal of Medicine. ... Some agencies own companies that ghost-write articles for medical journals." ${ }^{42}$

\section{Regaining control}

Beyond these problems of promotion lie a litany of stories revealed in the press in recent years about immoral and sometimes corrupt behaviours of pharmaceutical companies, including ostensibly the most reputable: about payoffs to generic producers not to rush in with cheaper drugs; about tactics used to delay the expiry of patents; about lawsuits and convictions, criminal and otherwise, concerning marketing fraud and the overbilling of government agencies; about blatant misinformation; about the co-optation and sometimes downright bribery of physicians, researchers and politicians. Examples of these behaviours, from articles in the prominent press and some major medical journals, are provided in Appendix I. Together, they tell a story of an industry that is out of social control.

The problem of high pharmaceutical prices is not without solutions. Many are obvious enough, and some have been implied in this article, including firmer regulation of pricing, the use of independent clearinghouses for balanced information on products, research efforts more widely spread across different types of institutions, and a stop to direct-to-consumer advertising. However, there is a lack of sufficient will to confront the problem directly, in part because of the power of the industry and its influence on political processes. The current situation in the patent-dependent pharmaceutical industry is not just unacceptable, it is shameful. It will remain so until concerned citizens gather the energy to change it.

\section{This article has been peer reviewed.}

Henry Mintzberg is Cleghorn Professor of Management Studies and Faculty Director of the International Masters for Health Leadership, Desautels Faculty of Management, McGill University, Montréal, Que.

Competing interests: None declared.

\section{REFERENCES}

I. McLean B, Llewellyn M. A bitter pill. Fortune 200I;I44:II8-22,I26,130-2.

2. Becker E. Drug industry seeks to sway prices overseas. New York Times 2003 Nov 27

3. Becker E. Trade deal opens Australia to U.S. manufactured goods. New York Times 2004 May 19.

4. Drahos P, Lokuge B, Faunce T, et al. Pharmaceuticals, intellectual property and free trade: the case of the US-Australia Free Trade Agreement. Prometheus 2004; 22:243-57.

5. Meyerson H. CAFTA's profit motive. W ashington Post 2005 Mar 30. 
6. CAFTA \& Public Health: Will poor people have access to medicines? [press release]. Oxfam America; 2004 Mar 22. Available: www.oxfamamerica.org/pdfs /cafta_ip_briefo404.pdf (accessed 2006 July 4).

7. US-Peru trade negotiations: Special Rapporteur on right to health reminds parties of human rights obligations [press release]. New York: United Nations; 2004 Jul 5.

8. Sontag D. Early tests for US in its global fight on AIDS. New York Times 2004 July I4

9. Short C, Secretary of State for International Development. Report to the Prime Minister: UK Working Group on Increasing Access to Essential Medicines in the Developing World: policy recommendations and strategy. 2002 Nov 28.) www.dfid .gov.uk/pubs/files/accessmedicines-report28II02.pdf (accessed 2006 Jul I7).

Io. McNeil DG. Indian company offers to supply AIDS drugs at low cost in Africa. New York Times 20or Feb 7 .

II. Swarns RL. Drug makers drop South Africa suit over AIDS medicine. New York Times 200I Apr 20.

I2. Hensley S. Trends (a special report): Pharmaceuticals — ads, co-pays and price gaps; drug maker, heal thyself. Wall Street Journal 2004 Feb 9.

I3. Taurel S. Hands off my industry. Wall Street Journal 2003 Nov 3.

I4. Dukes MNG. Accountability of the pharmaceutical industry. Lancet 2002;360:1682-4.

I5. Carey J. Drug R\&D: Must Americans always have to pay? Business Week 2003 Oct I3:38-40.

I6. Carey J, Barrett A, Weintraub A, et al. Drug prices: What's fair? Business Week 200 Dec Io:60-8.

I7. Pharmaceuticals. Mercky prospects. Economist 2002;364:5I-2.

I8. Taylor D. Fewer new drugs from the pharmaceutical industry [editorial]. BMJ 2003;326:408-9.

I9. Landers P. Drug industry's big push into technology falls short. Wall Street Journal 2004 Feb 24;Sect AI.

20. Light DW, Lexchin J. Will lower drug prices jeopardize drug research? A policy fact sheet. Am J Bioeth 2004;4(I):W3-W6.

2I. Lee TH. "Me-too" products: Friend or foe? N Engl J Med 2004;350:21I-2.

22. Clifford L. Tyrannosaurus Rx. Fortune (Europe) 2000;I42(I0):84-9I.

23. Landers P, Lublin JS. Under a microscope: Merck's big bet on research by its scientists comes up short. Wall Street Journal 2003 Nov 28;Sect AI.

24. Harris G. Where are all the new drugs? New York Times 2003 Oct 5;Sect 3:I.

25. Bowe C, Dyer G. Pfizer seeks a way to climb "the cliff." Financial Times 2004 May 3

26. Mintzberg H. The structuring of organizations: a synthesis of research. Englewood Cliffs (NJ): Prentice-Hall; i979. p. 223-40.

27. Henry D, Lexchin J. The pharmaceutical industry as a medicines provider. Lancet 2002;360:1590-5

28. The search for an AIDS vaccine [editorial]. New York Times 200I Apr 23.
29. Trouiller P, Olliaro P, Torreele E, et al. Drug development for neglected diseases: a deficient market and a public-health policy failure. Lancet 2002;359:2188-94

30. Collier J, Iheanacho I. The pharmaceutical industry as an informant. Lancet 2002; 360:1405-9.

31. Angell M. Is academic medicine for sale? [editorial] N Engl J Med 2000;342(20): I516-8.

32. Bodenheimer T. Uneasy alliance - clinical investigators and the pharmaceutical industry. NEngl J Med 2000;342(20):1539-44.

33. Terry R. Economic insanity. San Francisco: Berrett-Koehler Publishers; I995. p. I56.

34. Congressional Joint Economic Committee [Senator Connie Mack, chair]. The benefits of medical research and the role of the NIH. 2000 May. Available: www.mco .edu/research/nih_research_benefits.pdf (accessed 2006 Jun 27).

35. Government Accountability Office Report to the Honorable Ron Wyden, US Senate. Technology transfer: NIH-private sector partnership on the development of Taxol. 2003 June. Available: http://wyden.senate.gov/leg_issues/reports/taxol.pdf (accessed 2006 Jun 27).

36. Commission on Intellectual Property Rights (CIPR). Integrating intellectual property rights and development policy. London (UK): CIPR; 2002. Available: www .iprcommission.org/graphic/documents/final_report.htm (accessed 2006 Jul I7).

37. Oxfam International. Undermining access to medicines: comparison of five US FTAs [briefing note]. 2004 June. Available: www.oxfamamerica.org/pdfs/fta _comparison.pdf (accessed 2006 Jul I7).

38. Harris G. A drug giant thinks it can grow still bigger. New York Times 2003 Jun I9; Sect C:I(col 2).

39. Shapiro D. Drug companies get too close for med school's comfort. New York Times 2004 Jan 20.

40. McCormick BB, Tomlinson G, Brill-Edwards P, et al. Effect of restricting contact between pharmaceutical company representatives and internal medicine residents on posttraining attitudes and behavior. JAMA 200I;286(16):1994-9.

4I. Lee TH, Brennan TA. Direct-to-consumer marketing of high-technology screening tests. NEngI J Med 2002;346(7):529-31.

42. Peterson M. Madison Ave. has growing role in the business of drug research. New York Times 2002 Nov 22

Correspondence to: Professor Henry Mintzberg, Desautels Faculty of Management, McGill University, Ioor Sherbrooke St. W, Montréal QC $\mathrm{H}_{3} \mathrm{~A}_{\mathrm{I}} \mathrm{G}_{5}$; fax $5 \mathrm{I} 4$ 398-3876; henry.mintzberg@mcgill.ca

\section{Appendix 1: Behaviours of pharmaceutical companies related to points made in the article}

\section{Blocking generic drugs}

- "In two flagrant cases, big drugmakers paid millions to generic operators who agreed not to rush in with cheaper drugs" (Carey J, Barrett A, Weintraub A, et al. Drug prices: What's fair? Business Week 2001 Dec 10:70).

- "GlaxoSmithKline agreed on Friday to pay $\$ 175$ million to settle a lawsuit alleging that the company had violated U.S. antitrust law by blocking cheaper generic forms of its Relafen arthritis medicine" (Drug maker agrees to pay \$175 million in lawsuit. New York Times 20047 Feb).

Prolonging patent rights

- In 2001, in reference to Eli Lilly's efforts to extend its patent rights on Prozac (to 38 years, in the assessment of one opponent): "Patent battles aren't fought just in the courts; they're also fought in federal agencies; in the patent office - and in the research labs and marketing divisions of the major pharmaceuticals companies. And in these latter realms there is not much doubt that Big Pharma has the advantage. Even when patents are set to expire 'naturally', the drugmakers have a raft of tactics to prolong their monopoly on a drug. 'In general the record is not a proud one,' says one former industry executive...” (McLean B, Llewellyn M. A bitter pill. Fortune 2001;144[Aug 13]:126).

- In 2002, The Lancet referred to "one popular delaying tactic" as the filing of "new frivolous patents, based on features such as the pattern on a tablet" (An innovative challenge to the pharmaceutical industry [editorial]. Lancet 2002;360:1341).

Marketing fraud and overbilling

- "Drug companies have paid a total of $\$ 1.6$ billion since 2001 to settle seven suits brought by whistle-blowers that accused them of marketing fraud and overbilling Medicare and Medicaid, according to a report released yesterday by an advocacy group. ... The defendants were AstraZeneca, Bayer, Dey, GlaxoSmithKline, Pfizer, and TAP Pharmaceuticals." (Harris G. Drug makers settled 7 suits by whistle-blowers, group says. New York Times 2003 Nov 6).

Bribing physicians

- In 2004, a New York Times columnist wrote, "about the shadowy system of financial lures that pharmaceutical companies have used to persuade physicians to favor their drugs": "Just about every big global drug company ... has received a federal subpoena. ... Last month Pfizer agreed to pay $\$ 430$ million and pleaded guilty to criminal charges involving the marketing of the pain drug Neurontin..." Astra Zeneca and TAP Pharmaceutical Products in 2001 "each pleaded guilty to criminal charges of fraud for inducing physicians to bill the government for some drugs that the 


\section{Appendix 1: continued}

company gave the doctors free." One hospital director of clinical research "said that Schering-Plough had "flooded the market with pseudo-trials'." He said physicians were paid $\$ 1000$ to $\$ 1500$ a patient for prescribing one of the company's products, while the patients or insurers had paid for their medication. The story even cited the case of a "cheque for $\$ 10000$ [that] arrived in the mail [of a physician] unsolicited." This was "in exchange for an attached 'consulting' agreement that required nothing -other than his commitment to prescribe the company's medicines" (Harris G. As doctor writes prescription, drug company writes a check. New York Times 2004 June 27).

- "Last week two new cases came to light that reveal the lengths to which companies will go to buy influence with doctors, pharmacists and other medical professionals. Reed Abelson reported in The Times on Jan. 24 about a whistleblower's lawsuit alleging that Medtronic had paid tens of millions of dollars in recent years to surgeons in a position to use and recommend its medical devices. In one particularly egregious example, a prominent Wisconsin surgeon received $\$ 400,000$ for just eight days of consulting. In last Saturday’s Times, Gardiner Harris and Robert Pear revealed that a Danish company paid a pharmacist, doctors' assistants and a drug store chain to switch diabetic patients to the company's high-priced insulin products." (Seducing the medical profession [editorial]. New York Times 2006 Feb 2;Sect A:22[col 1]).

- "The public image of the medical profession has been hurt by doctors who accept freebies from pharmaceutical companies. So the American Medical Association [AMA] recently launched a campaign to remind its members about the AMA's ethical guideline. The campaign budget of $\$ 750,000$ comes mostly from the pharmaceutical business. ... The medical association seems to be working with the corporations to combat corporate influence. ... On the other side [of this donation to the AMA] sits the $\$ 16$ billion the industry spent last year on gifts and free drug samples." (An unhealthy influence on doctors [editorial]. New York Times 2001 Sept 10;Sect A:28[col 1]).

- A physician threw a pharmaceutical salesman out of his office after "repeated offers of free weekend trips to Florida to discuss pain management." The painkiller in question "has been a factor in the deaths of at least 120 people. ..." An official of the US Drug Enforcement Administration "said no other prescription drug in the last 20 years had been abused by so many people so soon after it had appeared." The company "often oversold OxyContin's benefits without adequately warning about its potential for abuse." (Meier B, Petersen M. Sales of painkiller grew rapidly, but success brought a high cost. New York Times 2001 Mar 5). Two years later, the maker of the painkiller, whose product had been reported as "addictive," ran an advertisement appearing "like a public service announcement" that presented the company "as part of the solution to nationwide abuse of its product." But OxyContin was "never mentioned." (Ives N. The maker of OxyContin, a painkiller that is addictive, sponsors a campaign in drug abuse. New York Times 2003 Sept 4).

\section{Biasing research}

- In a New England Journal of Medicine editorial "to discuss the extent to which academic medicine has become intertwined with the pharmaceutical and biotechnology industries," the author commented that "as we spoke with research psychiatrists about writing an editorial on the treatment of depression, we found very few who did not have financial ties to drug companies that make antidepressants... The problem is by no means unique to psychiatry. We routinely encounter similar difficulties in finding editorialists in other specialties, particularly those that involve the heavy use of expensive drugs and devices. ...The ties between clinical researchers and industry include not only grant support, but also a host of other financial arrangements. Researchers serve as consultants to companies whose products they are studying, join advisory boards and speakers' bureaus, enter into patent and royalty arrangements, agree to be the listed authors of articles ghostwritten by interested companies, promote drugs and devices at company-sponsored symposiums, and allow themselves to be plied with expensive gifts and trips to luxurious settings. Many also have equity interest in companies. ... Academic medical institutions are themselves growing increasingly beholden to industry. ... Some ... have entered into partnerships with drug companies to set up research centers and teaching programs in which students and faculty members essentially carry out industry research. ... The time-honored custom of drug companies' gaining entry into teaching hospitals by bestowing small gifts on house officers has reached new levels of munificence. Trainees now receive free meals and other substantial favors from drug companies virtually daily, and they are often invited to opulent dinners and other quasi-social events to hear lectures on various medical topics. All of this is done with the acquiescence of the teaching hospitals." (Angell M. Is academic medicine for sale? [editorial] N Engl J Med 2000;342:1516-8).

- "Stelfox et al. found that authors whose work supported the safety of calcium-channel antagonists had a higher frequency of financial relationships with the drugs' manufacturers than authors whose work did not support the safety of these medications. Davidson reported that results favoring a new therapy over a traditional one were more likely if the study was funded by the new therapy's manufacturer. Cho and Bero demonstrated that articles from symposiums sponsored by a single drug company were more likely than articles without company support to have outcomes favorable to the sponsor's drugs. Friedberg et al. reported that 5 percent of industry-sponsored pharmacoeconomic studies of cancer drugs reached unfavorable conclusions about the company's products, as compared with 38 percent of studies with nonprofit funding that reached similar conclusions." (Bodenheimer T. Uneasy alliance - clinical investigators and the pharmaceutical industry. N Engl J Med 2000;342:1539-44).

Infiltrating government

- In a 2002 article in The Lancet, Abraham discussed "the many ways in which the pharmaceutical industry can influence governments and regulatory agencies." For example, "In 2001, an internal inquiry into the view of regulatory staff at the FDA's Center for Drug Evaluation and Review reported that a third of respondents did not feel comfortable 


\section{Appendix 1: continued}

expressing their scientific opinions, with some reporting pressure to favour the wishes of manufacturers over the interests of science and public health, and receiving requests from senior agency officials to alter their opinions." Moreover, "The pharmaceutical industry has managed not only to gain key positions of influence over drug regulation but also to persuade governments and their regulatory agencies that other interested parties, such as consumer organizations, patients' associations, and the wider medical and scientific community, should have few or no rights of access to the regulatory process." (Abraham J. The pharmaceutical industry as a political player. Lancet 2002;360:1498-502).

- "It turns out that someone had tucked into a nook or cranny of the [Homeland Security Bill] a little parasite of a provision that will allow the pharmaceutical company Eli Lilly to perhaps get dismissed - or at least to hamper lawsuits by parents who claim that the preservative Thimerosal, used in Lilly vaccines, caused autism in their children." (Kelly M. What now? Atlantic Monthly 2003;Jan/Feb:32).

- "Having spent more than $\$ 30$ million to help elect their allies to the U.S. Congress, major drug companies are looking to capitalize on favorable new legislation. ... Executives of the major drug manufacturers [including the chief executives of Wyeth, Merck, and Eli Lilly] met last week ... to discuss specific ways to leverage their investment in this year's elections to advance their agenda on Capitol Hill. ... A pervasive theme of the discussions was how to block proposals that could erode profits by limiting drug prices or making it easier for people to buy low-cost generic versions of brand-name medicines." (Pear R, Oppel RA Jr. Results of elections give pharmaceutical industry new influence in Congress. New York Times 2002 Nov 21).

- One year later: "The legislation passed by Congress this week to establish a prescription drug benefit in the Medicare program specifically forbids the government to use its influence to negotiate lower drug prices. That provision was a top goal of the drug industry..." (Becker E. Drug industry seeks to sway prices overseas. New York Times 2003 Nov 27).

- "One reason the [pharmaceutical] industry does so well in the [US] capital is its patent lobby. It maintains more than 600 lobbyists - more than one for every member of Congress. It spent \$435 million to influence Washington from 1996 to 2003 and handed out $\$ 57.9$ million in contributions from 1991 to 2002, according to Common Cause. (Barlett DL, Steele JB, Karmatz L, et al. Why we pay so much for drugs. Time 2004 Feb 2;163[5]).

A consequence of all this

- The New York Times in July 2004 ran an article about the "dismal public standing" of Pfizer and the pharmaceutical industry in general. A Harris poll in the United States put it at the bottom of the rankings, with tobacco companies, and only $13 \%$ of respondents described the companies as "generally honest and trustworthy." A former chairman of Merck condemned drug makers "for the exorbitant prices of new medicines and 'galloping' annual increases of old ones. ... 'This industry delivered miracles, and now they're throwing it all away', [he] said. 'They just don't get it' ” (Harris G. Drug makers seek to mend their fractured image. New York Times 2004 July 8). 